\title{
Kepemimpinan Kepala Dinas KOPERINDAG Provinsi Gorontalo
}

\author{
Hasrul Arafa ${ }^{1)}$, Arianto Chanan²), Abd Kiftir Albakir ${ }^{3)}$ \\ ${ }^{122) 33}$ Mahasiswa Jurusan Pendidikan Ekonomi, Universitas Negeri Gorontalo \\ hasrularafa01@yahoo.com
}

\begin{abstract}
This study ained to analyze the influence of leadership style and the availability of facilities on the performance of employees at the coopertives, SMEs, Industry, and Trade Office of Gorontalo Province. This quantitative research employed proportional random sampling as the sampling technique. From a population of 117 people, this study attained 31 people as samples.

The data was abtained from a research questionnaire and processed using Microsoft excel program and SPSS statistics. The findings of the study showed that: 1) Pertially, the leadership style had positive effect an employee performance with an average score of 3.91. this indicated that the leadership style applied in the aforementioned area was a Democratic Leadership Style. 2) Pertially, the work facilities had a positive influence on employee performance with an average value of 4.56. This, the existing office facilities at the research site were in very good criteria. 3) Jointly, the leadership style and facilities had an influence on employee performance by $29.6 \%$.
\end{abstract}

\section{Keywords: Leadership Style, Work Facilities and Employee Performance}

PENDAHULUAN

\section{Latar Belakang}

Dinas Koperasi, UMKM, Perindustrian dan Perdagangan Provinsi Gorontalo merupakan salah satu instansi yang turut berpengaruh dan memiliki andil dalam pembangunan ekonomi masyarakat. Sebahagian dari perjalanan Gorontalo, membangun ekonomi melalui kebijakan pembangunan di bidang Koperasi, Usaha Mikro Kecil dan Menengah (UMKM), Industri Kecil Menengah (IKM) dan perdagangan diselenggarakan oleh Dinas Koperasi, UMKM, Perindustrian dan Perdagangan Provinsi Gorontalo. 
Dalam upaya peningkatan kinerja dan citra instansi ke arah profesionalisme dan tercapainya pemerintahan yang baik (Good Governance) perlu adanya penyatuan persepsi bagi setiap jajaran pegawai yang dapat dipergunakan sebagai pedoman dalam melaksanakan tugas baik manajerial maupun operasional di seluruh bidang tugas dan unit instansi secara terpadu.

Tinggi rendahnya sumber daya, dilihat dari kinerja pegawai dan kualitas pelayanan dapat diukur sejauh mana aktifitas dan efisiensi dalam memberikan pelayanan kepada masyarakat. Faktor-faktor yang diperhitungkan gairah kerja pegawai adalah kualitas sumber daya dan kinerja yang dimiliki seorang aparatur dalam melayani masyarakat. Kualitas sumber daya yang dimiliki dan kinerja merupakan nilai-nilai yang harus diaplikasikan kepada seluruh aparat agar menyadari, bahwa mereka adalah pelayanan masyarakat yang berkewajiban, yang bertanggung jawab penuh dalam rangka mengemban tugas-tugas yang diberikan oleh sebuah instansi pemerintah.

Salah satu permasalahan yang dihadapi disini adalah rendahnya kinerja yang dimiliki pegawai. Agus Dharma (2016) berpendapat bahwa: kinerja pegawai adalah sesuatu yang dicapai oleh pegawai, prestasi kerja diperhatikan oleh pegawai, kemampuan kerja berkaitan dengan peralatan kantor. Sejalan dengan pengertian tersebut, penggunaan alat kantor disini merupakan sarana dalam membantu pegawai agar bisa melaksanakan tugasnya dengan optimal. Oleh karena itu diperlukan pengelolaan sarana dan prasarana yang bisa memfasilitasi pegawai dalam melakukan pekerjaannya.

Sarana dan prasarana adalah alat yang diperlukan untuk menggerakkan kegiatan manajemen dalam rangka mencapai tujuan organisasi (Djiyowirono, 2015). Selain itu, untuk menunjang kinerja pagawai agar lebih baik perlu adanya gaya kepemimpinan. Tanpa kepemimpinan yang efektif, suatu organisasi tidak akan pernah mampu mengaktualisasikan potensi menjadi prestasi. Kepemimpinan seharusnya dipersepsikan sebagai suatu peluang untuk memberikan manfaat bagi banyak pihak dan bukan dipersepsikan sebagai komoditi atau properti untuk mengambil keuntungan diri sendiri melalui pemanfaatan pihak lain. Esensi kepemimpinan dalam organisasi apapun sangat diperlukan kehadiran dan perannya, sekalipun dalam organisasi itu telah ditata struktur dan mekanisme kerja sedemikian sempurna. Kepemimpinan berperan untuk menserasikan kepentingan antar berbagai pihak. Wexley \& Yulki (1998) berpendapat bahwa kepemimpinan mengandung arti mempengaruhi orang lain untuk 
lebih berusaha mengarahkan tenaga, dalam tugasnya atau mengubah tingkah laku mereka.

Gaya kepemimpinan dapat dikatakan baik jika gaya kepemimpinan tersebut dapat diterapkan oleh seorang pemimpin dengan baik dan dapat diterima pegawai/karyawan yang ada dalam organisasi tersebut sehingga kinerja pegawai tersebut dapat ditingkatkan. Apabila kinerja pegawai dapat dijalankan dengan baik, maka hal ini akan berdampak baik pada pencapaian tujuan organisasi. Dengan gaya kepemimpinan yang sesuai maka seorang pemimpin harus dapat berkomunikasi dengan baik dan dapat bekerja sama dalam hal tugas dan tanggungjawab.

\section{Tujuan Penelitian}

Tujuan penelitian adalah sebagai berikut:

1. Untuk mengetahui pengaruh gaya kepemimpinan terhadap kinerja pegawai.

2. Untuk mengetahui pengaruh fasilitas kerja terhadap kinerja pegawai.

3. Untuk mengetahui apakah gaya kepemimpinan dan fasilitas kerja berpengaruh secara simultan terhadap kinerja pegawai.

\section{Manfaat Penelitian}

sebagai berikut:

Manfaat penelitian adalah

1. Bagi Organisasi

Diharapkan dapat memberikan masukan kepada Dinas Koperasi
UKM Perindustrian dan Perdagangan, mengenai gaya kepemimpinan dan fasilitas kerja dalam meningkatkan kinerja pegawai.

2. Bagi Universitas

Diharapkan dapat dijadikan bahan referensi bagi peneliti lain yang akan melakukan penelitian sejenis dan dapat digunakan sebagai bahan perbandingan.

3. Bagi Peneliti

Penelitian ini dapat memberikan pengetahuan dan pengalaman dalam menyusun sebuah karya ilmiah berupa skipsi yang menjadi syarat dalam mengikuti ujian akhir guna memperoleh gelar sarjana.

\section{KAJIAN TEORI}

\section{Kinerja Pegawai}

Anwar Prabu Mangkunegara (2009:67) mengemukakan bahwa kinerja adalah hasil kerja secara kualitas dan kuantitas yang dicapai oleh seorang pegawai dalam melaksanakan tugasnya sesuai dengan tanggung jawab yang diberikan kepadanya. Rivai dan Basri, (2005:50). Ber-pendapat bahwakinerjaadalah hasil atau tingkat keberhasilan seseorang secarakeseluruhanselama periode tertentu dalam melaksanakan tugas dibandingkan dengan berbagai kemungkinan, seperti standar hasil kerja, target atau sasaran atau kriteria 
yang telah ditentukan terlebih dahulu telah disepakati bersama.

\section{Karakteristik Kinerja Pegawai}

Karakteristik orang yang mempunyai kinerja tinggi menurut Mangkunegara (2012: 68) adalah sebagai berikut:

1. Memiliki tanggung jawab pribadi yang tinggi.

2. Berani mengambil dan menanggung resiko yang dihadapi.

3. Memiliki tujuan yang realistis.

4. Memiliki rencana yang menyeluruh dan berjuan untuk merealisasikan tujuannya.

5. Memanfaatkan umpan balik yang kongkrit dalam seluruh kegiartan kerja yang dilakukannya.

6. Mencari kesempatan untuk merealisasikan rencana yang telah diprogramkan.

Indikator Kinerja

Indikator untuk mengukur kinerja secara individu, yaitu (Robbins, 2006:260)

1. Kualitas

Kualitas kerja diukur dari persepsi karyawan terhadap kualitas pekerjaan yang dihasilkan serta kesempurnaan tugas terhadap keterampilan dan kemampuan karyawan.

2. Kuntitas

Merupakan jumlah yang dihasilkan dinyatakan dalam istilah seperti jumlah unit, jumlah siklus aktivitas yang dilaksanakan.
3. Ketepatan waktu

Merupakan tingkat aktivitas diselesaikan pada awal waktu yang dinyatakan, dilihat dari sudut koordinasi dengan hasil output serta memaksimalkan waktu yang tersedia untuk aktivitas lain.

4. Efektivitas

Merupakan tingkat penggunaan sumber daya organisasi (tenaga, uang, teknologi, bahan baku) dimaksimalkan dengan maksud menaikkan hasil dari setiap unit dalam penggunaan sumber daya.

5. Kemandirian

Merupakan suatu tingkat dimana karyawan mempunyai komitmen kerja dengan instansi dan tanggung jawab karyawan karyawan terhadap kantor.

\section{Gaya Kepemimpinan}

Menurut Wiyono (2009), kepemimpinan terdiri dari tiga unsur yang saling berkaitan yaitu unsur manusia, unsur sarana dan unsur tujuan. Ketiga unsur tersebut harus dilakukan secara seimbang, seorang pemimpin harus mempunyai pengetahuan atau kecakapan dan keterampilan dalam melaksanakan kepemimpinannya. Pengetahuan dan keterampilan ini diperoleh dari pengalaman belajar secara teori ataupun pengalamannya di dalam praktik selama menjadi pemimpin. Secara tidak disadari seorang pemimpin memperlakukan ketiga unsur tersebut dengan caranya sendiri. 
Cara-cara yang digunakannya merupakan pencerminan dari sifat-sifat dasar kepribadian seorang pemimpin. Cara atau teknik seorang dalam menjalankan kepemimpinannya disebut tipe atau gaya kepemimpinan (Wiyono, 2009).

\section{Kepemimpinan dalam Peningkatan Kinerja}

Menurut Mulyasa (2017:117), kegagalan dan keberhasilan suatu organisasi banyak ditentukan oleh pemimpin karena pemimpin merupakan pengendali dan penentu arah yang hendak ditempuh oleh organisasi menuju tujuan yang akan dicapai. Hal ini sejalan dengan apa yang dikemukakan oleh Siagian (2014:49), bahwa arah yang hendak ditempuh oleh organisasi menuju tujuan harus sedemikian rupa sehingga mengoptimalkan pemanfaatan dari segala sarana dan prasarana yang tersedia. Arah yang dimaksud tertuang dalam strategi dan taktik yang disusun dan dijalankan oleh organisasi yang bersangkutan. Perumus serta penentu strategi dan taktik adalah pimpinan dalam organisasi tersebut.

Menurut Simandjuntak (dalam staffmm, 2007) bahwa kinerja seseorang bisa dipengaruhi beberapa faktor diantaranya adalah kepemimpinan, hubungan industrial, kemampuan dan ketrampilan, motivasi sikap, etos kerja, struktur orgaisasi, teknologi dan peralatan atau fasilitas kerja dan kondisi kerja. Penerapan gaya kepemimpinan yang tepat akan mempunyai pengaruh yang berarti dalam pengambilan keputusan, maupun dalam mempengaruhi pegawai untuk melakukan pekerjaan yang lebih efisien dan efektif untuk mencapai kinerja pegawai yang baik.

\section{Fasilitas Kerja}

Menurut Moekijat (2001: 155) secara sederhana yang dimaksud dengan fasilitas adalah suatu sarana fisik yang dapat memproses suatu masukan (input) menuju keluaran (output) yang diinginkan. Fasilitas adalah sarana untuk melancarkan dan memudahkan pelaksanaan fungsi. Fasilitas merupakan komponen individual dari penawaran yang mudah ditumbuhkan atau dikurangitan pamengubah kualitas dan model jasa. Fasilitas juga merupakan alat untuk membedakan program lembaga pendidikan yang satu dari pesaing yang lainnya (Lupiyaodi, 2006:150). Nitisemito (2001:65) mengemukakan fasilitas adalah rasa menyenangkan yang diberikan kepada orang lain disertai kemudahan untuk memenuhi kebutuhan mereka. Fasilitas ini sangat sulit didefinisikan karena:

a. Sifatnya tidak bisa di ukur, sifatnya lebih berorientasi kepada perasaan orang lain terhadap fasilitas yangdiberikan.

b. Kita bias menjualnya, tapi tidak memberikan sampel dari fasilitas itu kepada pihak lain untuk dibawa dan diperhatikan kepada pihak lain untuk dibawa dan 
diperlihatkan kepada oranglain.

c. Setelah fasilitas diberikan, orang lain mungkin merasa mendapatkan fasilitas yang sesuai atau tidak sesuai dengan yang diharapkan.

d. Sulit untuk distandarisasi

Menurut Allen (dalam Suhardi 2001:59) fungsi fasilitas secara umum adalah sebagai berikut:

a. Untuk mengalokasikan secara efisien sumber tenaga pekerjake arah pekerjaan-pekerjaan yang kurang dapat memberikan kontribusi yang lebih wajar. Ini berarti bahwa fasilitas dapat membantu para pekerja dari pekerjaan tambahan yang akan dilaksanakan diluar jam kerja, dengan kata lain para pekerja akan betah dengan pekerjaan yang dilakukannya.

b. Untuk mengadakan sumbersumber tenaga kerja yang efisien.

Pemberian fasilitas yang tinggi akan memaksa suatu lembaga atau instansi memanfaatkan tenaga kerja secara ekonomis atau seefisien mungkin (tentunya dikombinasikan dengan faktorfaktor produksi lainnya).

c. Menghubungkan penerimaan dengan kontribusi produktivitasnya perusahaan berarti memberikan fasilitas yang tinggi, apabila pekerjaan para karyawan tinggi tingkat produktivitasnya.

d. Untuk menghubungkan pemberian fasilitas dengan finansial perusahaan. Semakin sukses finansial perusahaan, sebaiknya skala pemberian fasilitas disesuaikan dengan kesuksesan secara proposional, dengan anggapan bahwa fasilitas yang disediakan sudah cukup memenuhi prinsip keadilan dan kelayakan.

\section{METODE PENELITIAN}

Metode yang digunakan dalam penelitian ini adalah survei dan metode kuantitatif. Menurut sugiono (2014:81) metode survei adalah metode penelitian kuantitatif yang digunakan untuk mendapatkan data yang terjadi pada masa lampau atau pada masa ini, tentang keyakinan, pendapat, perilaku, karakteristik hubungan variabel dan untuk menguji beberapa hipotesis tentang sosiologis dan psikologis dari sampel yang diambil dari populasi sampel tertentu, teknik pengamatan dengan menggunakan kuesioner yang tidak mendalam dan hasil penelitian cenderung untuk digeneralisasikan.

Metode kuantitatif adalah metode penelitian yang berlandaskan pada filsafat positivisme, digunakan untuk meneliti pada populasi atau sampel tertentu, pengumpulan data bersifat kuantitatif/statistik dengan tujuan untuk menguji hipotesis yang telah ditetapkan (Sugiono, 2014:36).

\section{Waktu Penelitian}

Penelitian ini berlangsung selama 6 bulan yakni dari bulan Mei s/d bulan Oktober 2020, di dalamnya 
mencakup semua langkah-langkah penelitian mulai dari tahap persiapan sampai pelaksanaan penelitian.

\section{Tempat Penelitian}

Penelitian ini dilaksanakan di

Dinas Koperasi UKM Perindustrian dan Perdagangan. Peneliti memilih Dinas KOPERINDAK untuk di jadikan tempat penelitian disebabkan peneliti men-dapatkan izin dari kepala Dinas KOPERINDAK untuk melakukan penelitian awal berupa observasi di kantor Dinas Koperasi UKM Perindustrian dan Perdagangan dan secara geografis berdekatan dengan tempat tinggal peneliti.

\section{Populasi}

Arikunto (2006:130) Populasi adalah keseluruhan subjek penelitian. Populasi yang dimaksud dalam penelitian ini adalah semua pegawai di Kantor Dinas Koperasi UKM Perindustrian dan Perdagangan yang berjumlah 171 orang.

\section{Sampel}

Arikunto (2006:131) adalah sebahagian atau wakil populasi yang diteliti. Pemilihan sampel dilakukan dengan cara sampel random atau acak, yaitu di dalam pengambilan sampelnya, peneliti "mencampur" subjek-subjek di dalam populasi sehingga semua subjek dianggap sama (Arikunto, 2006:134). Sampel yang ditetapkan oleh peneliti dalam penelitian ini adalah 31 orang.

\section{Analisis Data}

Peneliti membagikan kuesioner kepada 31 orang responden, kuesioner diisi oleh responden dengan memberikan tanda $(X)$ pada setiap butir per-tanyaan dicantumkan pilihan yaitu "SS" sangat setuju, "S" setuju, "N" netral, "TS" tidak setuju, "STS" sangat tidak setuju.

Analisis deskriptif akan memaparkan skor rata-rata variabel, sedangkan analisis data kuantitatif terhadap variabel independent dan dependent meliputi uji instrument (validitas dan reabilitas), uji asumsi klasik (uji normalitas). Uji heteroskedastisitas, uji multikolinearitas dan uji regresi linear berganda. Pengolahan data menggunakan software perangakat lunak Microsoft Exel dan analisis data menggunakan software perangkat lunak SPSS.

\section{Analisis Deskriptif}

$$
\text { Menurut Trochim }
$$

Statistik deskriptif hanya menggambarkan data atau seperti apa data ditunjukkan. Data berupa rata-rata (mean) dari setiap pertanyaan kuesioner yang akan dianalisis merupakan hasil jawaban responden terhadap penelitian.

\section{Analisis Regresi Linear Berganda}

Analisis regresi linear berganda digunakan digunakan untuk mengetahui besarnya pengaruh variabel independent Gaya Kepemimpinan $\left(X_{1}\right)$ dan Fasilitas Kerja $\left(X_{2}\right)$ terhadap variabel dependent Kinerja Pegawai (Y). 


\section{Hipotesis}

$\mathrm{H}_{1}=$ ada pengaruh positif signifikan gaya kepemimpinan terhadap kinerja pegawai Dinas Koperasi UKM Perindustrian dan Perdagangan.

$\mathrm{H}_{2}$ = ada pengaruh positif signifikan ketersediaan fasilitas terhadap kinerja pegawai Dinas Koperasi UKM Perindustrian dan Perdagangan.

$\mathrm{H}_{3}=$ ada pengaruh positif signifikan antara gaya kepemimpinan dan ketersediaan fasilitas secara simultan terhadap kinerja pegawai Dinas Koperasi UKM Perindustrian dan Perdagangan.

\section{HASIL DAN PEMBAHASAN}

\section{A. Gambaran Umum Lokasi Penelitian}

Dinas Koperasi UKM Perindustrian dan Perdagangan Provinsi Gorontalo awalnya terbentuk dengan nama Dinas Perindustrian Perdagangan dan Tenaga Kerja Provinsi Gorontalo pada tanggal 21 Februari 2001 sampai 11 Maret 2002 yang dikepalai oleh ibu Hj. Etty Yusnani, SE, MM Seiring dengan pembangunan daerah, Dinas ini sudah mengalami 3 (tiga) kali perubahan nama, pada tahun 2002 berubah menjadi Dinas Perindustrian Perdagangan dan Penanaman Modal, dan kemudian dalam Peraturan Daerah Nomor 6 Tahun 2007 berubah menjadi Dinas Koperasi, Perindustrian dan Perdagangan Provinsi Gorontalo, dan sesuai Pergub nomor 12 tahun 2013 tentang pembentukan OTK Dinas Koperasi, Perindustrian dan Perdagangan Provinsi Gorontalo diganti menjadi Dinas Koperasi, UMKM, Perindustrian dan Perdagangan Provinsi Gorontalo dan terakhir Januari 2017 pembentukan OPD sesuai Pergub 67 tahun 2016 diganti menjadi Dinas Koperasi, UKM, Perindustrian dan Perdagangan Provinsi Gorontalo sekarang dijabat oleh Drs. Hi. M. Nadjamuddin. Selama berdirinya Dinas Koperasi UKM Perindustrian dan Perdagangan Provinsi Gorontalo telah mengalami beberapa kali pergantian Kepala Dinas (Eselon II) yaitu;

1. Hj. Etty Yusnani, SE, MM

Tahun 2001 - 2002

2. Ir. Ramli Usman, M.BA

Tahun 2002 -2003

3. Drs. Djaridin Nento, M.SI

Tahun 2003 - 2004

4. Drs. Erman Djafar

Tahun 2004 - 2009

5. Drs. Syukri J. Botutihe, M.SI

Tahun 2009 -2011

6. DR. Fachrudin Z. Olilingo, SE, M.SI Tahun 2011 - 2012

7. Drs. Arjon Paris Tahun 2012 - 2014

8. Drs. Abdul Haris Hadju, M.M Tahun 2014 - 2018

9. Drs. H. M. Nadjamuddin, M.M Tahun 2018 Sampai Sekarang 


\section{B. Hasil Penelitian}

\section{Analisis Uji Validitas}

Analisis uji validitas penelitian ini dilakukan dengan mencari nilai korelasi Product Moment (Pearson) antara masing-masing item dengan skor total, dengan taraf signifikansi $(\alpha)=5 \%$ dan derajad ke bebasan $(\mathrm{dk}=\mathrm{n}$ 2), yaitu $d k=31-2$. Butir pernyataan dikatakan valid jikar hitung lebih besar dari rtabel. Butir pernyataan dikatakan tidak valid jika rhitung lebih kecil dari $r_{\text {tabel }}$

Tabel 4.1

Hasil Uji Validitas Gaya Kepemimpinan

\begin{tabular}{|c|c|c|c|}
\hline Pertanyaan & $\begin{array}{c}\text { Nilai r- } \\
\text { tabel }\end{array}$ & $\begin{array}{c}\text { Nilai r- } \\
\text { hitung }\end{array}$ & Ket \\
\hline 1 & 0,355 & 0,552 & Valid \\
\hline 2 & 0,355 & 0,622 & Valid \\
\hline 3 & 0,355 & 0,714 & Valid \\
\hline 4 & 0,355 & 0,619 & Valid \\
\hline 5 & 0,355 & 0,638 & Valid \\
\hline 6 & 0,355 & 0,575 & Valid \\
\hline 7 & 0,355 & 0,390 & Valid \\
\hline 8 & 0,355 & 0,497 & Valid \\
\hline
\end{tabular}

Sumber: Data Primer, Diolah Tahun 2020

Berdasarkan tabel 4.1 hasil uji validitas menggunakan program SPSS 21 , pernyataan gaya kepemimpinan dinyatakan memenuhi syarat yang berarti item pertanyaan kuesioner gaya kepemimpinan dapat digunakan.
Tabel 4.2

\section{Hasil Uji Validitas Fasilitas Kerja}

\begin{tabular}{|c|c|c|c|}
\hline $\begin{array}{c}\text { Pertanyaa } \\
\mathrm{n}\end{array}$ & $\begin{array}{c}\text { Nilai } \mathrm{r}- \\
\text { tabel }\end{array}$ & $\begin{array}{c}\text { Nilai } \mathrm{r}- \\
\text { hitung }\end{array}$ & Ket \\
\hline 1 & 0,355 & 0,549 & Valid \\
\hline 2 & 0,355 & 0,570 & Valid \\
\hline 3 & 0,355 & 0,848 & Valid \\
\hline 4 & 0,355 & 0,708 & Valid \\
\hline 5 & 0,355 & 0,393 & Valid \\
\hline 6 & 0,355 & 0,747 & Valid \\
\hline 7 & 0,355 & 0,522 & Valid \\
\hline 8 & 0,355 & 0,385 & Valid \\
\hline
\end{tabular}

Sumber: Data Primer, Diolah Tahun 2020

Berdasarkan tabel 4.2 hasil uji validitas fasilitas kerja dinyatakan valid, pernyataan fasilitas kerja memenuhi syarat sehingga item pertanyaan kuesioner fasilitas kerja dapat digunakan.

Tabel 4.3

Hasil Uji Validitas Kinerja Pegawai

\begin{tabular}{|c|c|c|c|}
\hline $\begin{array}{c}\text { Pertanyaa } \\
\mathrm{n}\end{array}$ & $\begin{array}{c}\text { Nilai r- } \\
\text { tabel }\end{array}$ & $\begin{array}{c}\text { Nilai r- } \\
\text { hitung }\end{array}$ & Ket \\
\hline 1 & 0,355 & 0,484 & Valid \\
\hline 2 & 0,355 & 0,377 & Valid \\
\hline 3 & 0,355 & 0,444 & Valid \\
\hline 4 & 0,355 & 0,744 & Valid \\
\hline 5 & 0,355 & 0,532 & Valid \\
\hline 6 & 0,355 & 0,609 & Valid \\
\hline 7 & 0,355 & 0,430 & Valid \\
\hline 8 & 0,355 & 0,613 & Valid \\
\hline 9 & 0,355 & 0,645 & Valid \\
\hline
\end{tabular}

Berdasarkan tabel 4.3 diatas menggunakan program SPSS, pernyataan kinerja pegawai dinyatakan memenuhi syarat uji validitas yang berarti item peryataan 
kuesioner kinerja pegawai dapat digunakan.

\section{Analisis Uji Reliabilitas}

Uji reliabilitas digunakan untuk mengetahui hasil pengukuran terhadap kuesioner akan tetap konsisten atau tidak konsisten.

Tabel 4.4

Hasil Uji Reliabilitas Gaya Kepemimpinan

\begin{tabular}{|r|r|}
\hline $\begin{array}{c}\text { Cronbach' } \\
\text { s } \\
\text { alpha }\end{array}$ & N of items \\
\hline .708 & 8 \\
\hline
\end{tabular}

Sumber: Data Primer, Diolah Tahun 2020

Berdasarkan tabel 4.4 dapat diketahui bahwa nilai reliabilitas variabel gaya kepemimpinan sebesar 0,708 . Hal ini berarti item pernyataan tentang gaya kepemimpinan dinyatakan reliabel.

Tabel 4.5

Hasil Uji Reliabilitas Fasilitas Kerja

\begin{tabular}{|r|r|}
\hline $\begin{array}{c}\text { Cronbach' } \\
\mathrm{s} \\
\text { alpha }\end{array}$ & N of items \\
\hline .732 & 8 \\
\hline
\end{tabular}

Sumber: Data Primer, Diolah Tahun 2020

Berdasarkan tabel 4.5 dapat diketahui bahwa nilai reliabilitas variabel fasilitas kerja sebesar 0,732. Hal ini berarti item pernyataan tentang fasilitas kerja dinyatakan reliabel.
Tabel 4.6

Hasil Uji Reliabilitas Kinerja Pegawai

\begin{tabular}{|r|r|}
\hline $\begin{array}{c}\text { Cronbach's } \\
\text { alpha }\end{array}$ & N of items \\
\hline .709 & 9 \\
\hline
\end{tabular}

Sumber: Data Primer, Diolah Tahun 2020

Berdasarkan tabel 4.6 dapat diketahui bahwa nilai reliabilitas variabel kinerja pegawai sebesar 0,709 . Hal ini berarti item pernyataan tentang kinerja pegawai dinyatakan reliabel.

\section{Uji Asumsi Klasik Uji Normalitas}

Uji statistik yang digunakan untuk menguji Normalitas Residual adalah Statistic non-parametric Kolmogorov-Smirnov. Metode pengujian normal tidaknya distribusi data dilakukan dengan melihat nilai signifikansi variabel. Jika nilai signifikansi lebih besar dari 5\% maka menunjukkan distribusi normal.

Tabel 4.7

Hasil Uji Normalitas

One-Sample Kolmogorov-Smirnov Test

Unstandardized Residual

\begin{tabular}{|l|l|r|}
\hline N & 31 \\
\hline \multirow{2}{*}{$\begin{array}{l}\text { Normal } \\
\text { Parameters }\end{array}$} & Mean &, 0000000 \\
\cline { 2 - 3 } & $\begin{array}{l}\text { Std. } \\
\text { Deviation }\end{array}$ &, 28676592 \\
\hline \multirow{2}{*}{$\begin{array}{l}\text { Most Extreme } \\
\text { Differences }\end{array}$} & Absolute &, 090 \\
\cline { 2 - 3 } & Positive &, 059 \\
\cline { 2 - 3 } & Negative &,- 090 \\
\hline Test Statistic &, 090 \\
\hline \multicolumn{2}{|l|}{ Asymp. Sig. (2-tailed) } &, $200^{c, d}$ \\
\hline
\end{tabular}

a. Test distribution is Normal.

Berdasarkan hasil pengujian pada

Tabel 4.7, hasil pengujian One-Sam. 


\section{PENUTUP}

\subsection{Simpulan}

Berdasarkan hasil analisis dan pembahasan dari hasil penelitian yang telah dilakukan pada Kantor Dinas KOPERINDAK, maka dapat diambil beberapa kesimpulan berikut menurut permasalahan yang diangkat oleh penulis, yaitu:

1. Gaya Kepemimpinan berpengaruh positif terhadap kinerja Karyawan di Kantor Dinas Koperasi UKM Perindustrian dan Perdagangan Provinsi Gorontalo. Berdasarkan analisis deskriptif, menunjukkan bahwa variabel gaya kepemimpinan memiliki nilai rata-rata sebesar 3,91. Hal ini menunjukkan bahwagayakepemimpinan yang diterapkan di Kantor Dinas KOPERINDAK adalah Gaya Kepe-mimpinan demokratis.

2. Fasilitas Kerja berpengaruh positif terhadap kinerja Karyawan di Kantor Dinas Koperasi UKM Perindustrian dan Perdagangan Provinsi Gorontalo. Berdasarkan analisis deskriptif, menunjukkan bahwa variabel fasilitas kerja memiliki nilai rata-rata sebesar 4,56. Dengan demikian fasilitas kerja yang ada di kantor Dinas KOPERINDAK berada pada kriteria sangat baik.

3. Fasilitas kerja dan Gaya kepemimpinan secara bersama-sama berpengaruh terhadap Kinerja Karyawan di Kantor Dinas Koperasi UKM Perindustrian dan
Perdagangan Provinsi Gorontalo. Hal ini ditunjukkan dari tabel V.19 bahwa fasilitaskerja dan Gaya Kepe-mimpinan memiliki pengaruh bersama-sama sebesar $29,6 \%$.

\subsection{Saran}

Berdasarkan hasil penelitian dan analisis yang dilakukan, maka penulis memberikan saran dengan harapan dapat berguna bagi perusahan dan penelitian selanjutnya.

1. Bagi pihak instansi

Dari hasil penelitian peneliti akan memberikan saran dengan melihat hasil data dari setiap variabel yang sudah diteliti. Pertama, dari segi fasilitas kerja, rata-rata terendah variabel fasilitas kerja pada item item pernyataan adalah item nomor $7(4,39)$ yaitu "kantor Dinas KOPERINDAK memilik ruang tamu untuk pengunjung". Hal ini menunjukkan ada baiknya pihak perusahaan untuk meningkatkan kualitas ruang tamu (ruang tunggu) bagi pengunjung. Dengan meningkatkan kualitas ruang tamu pengunjung tentunya akan lebih meningkatkan kenyamanan bagi para pengunjung. Dan rata-rata tertinggi variabel fasilitas kerja pada item-item pernyataan adalah item nomor $1(4,74)$ yaitu " Tersedianya fasilitas alat kerja berupa seperangkat komputer (komputer / laptop), CPU, dan Printer)", ada baiknya pihak perusahaan tetap mempertahankan ketersediaannya fasilitas alat kerja ini guna semakin meningkatkan kinerja pegawainya, tentunya pihak 
perusahaan diharapkan agar tetap menjaga peralatan-peralatan (seperangkat komputer / laptop, CPU dan printer) sehingga dapat digunakan dalam tempo yang lebih lama lagi. Kedua, atau yang terakhir dari segi kinerja pegawai rata-rata terendah vareabel kinerja pegawai adalah item pernyataan nomor $5(3,81)$ "Saya selalu merasa puas dengan hasil kerja saya". Hal ini dapat disimpulkan bahwa para pegawai /karyawan yang ada di kantor Dinas bekerja dengan sangat baik. Dalam artian, para pegawai tidak pernah merasa puas dalam mengerjakan tugas-tugasnya. Hal ini tentunya diharapkan dapat dipertahankan oleh pihak Kecamatan agar kinerja pegawai dapat lebih baik lagi kedepannya. Dan rata-rata tertinggi variabel kinerja pegawai adalah item pernyataan nomor $1(4,71)$ "Saya selalu berusaha untuk menyelesaikan tugastugas yang diberikan perusahaan dengan tepat waktu". Hal ini menunjukkan bahwa para pegawai Kantor Dinas KOPERINDAK selalu berusaha untuk disiplin dan menaati peraturan yang diterapkan oleh pihak Kecamatan, dan diharapkan dapat dipertahankan guna menunjang kinerja pegawai yang lebih baik lagi kedepannya.

2. Bagi peneliti selanjutnya

a. Penelitian selanjutnya diharapkan meneliti kecamatan-kecamatan lainnya yang sejenis sehingga penelitian dapat digeneralisasikan. b. Penelitian selanjutnya juga disarankan untuk memperkaya ranah penelitian menambah variabelvariabel yang belum diuji dalam penelitian ini.

\section{DAFTAR PUSTAKA}

Arikunto, Suharsimi. 2006. Prosedur Penelitian Suatu Pendekatan Praktik. Jakarta: Rineka Cipta

Anwar Prabu Mangkunegara, (2002), "Manajemen Sumber Daya Manusia". PT. Remaja Rosda

Karya. Bandung.

AnwarPrabuMangkunegara, 2005.

Evaluasi Kinerja SDM. Bandung. Penerbit: PT. Refika Aditama.

Basri, A.F.M., dan Rivai, V. 2005. Performance Appraisal. Jakarta. Penerbit: PT. Raja Grafindo Persada.

Darma, Agus. 2016. Manajemen Prestasi Kerja. Jakarta: CV. Rajawali Diah Ayu.

Ghozali, Imam. (2005). Aplikasi Analisis Multivariate Dengan

Program SPSS. $\quad$ Semarang:

Badan Penerbit Universitas

Diponegoro.

Hariandja Efendi, Tua Marihot. 2005. Pengadaan, Pengembangan,

Pengkompensasian, dan Peningkatan Produktivitas Pegawai. Jakarta: PT. Grasindo.

Lupiyoadi, Hamdani. 2006. Manajemen Pemasaran Jasa, Edisi Kedua. Jakarta: Penerbit Salemba Empat. 
Moekijat.2001. Manajemen Personalia dan Sumber Daya Manusia.

Robbins. 2006. Perilaku Organisasi. Edisi Jakarta. Penerbit: PT. Indeks Kelompok Gramedia

Suhardi. 2001. Organisasi dan Motivasi.

Yogyakarta. Penerbit: Gaya

Media

Sugiyono. 2014. Metode Penelitian

Manajemen. Bandung.

Penerbit: CV.Alfabeta. 